\title{
An Analysis of Factors Affecting on Online Shopping Behavior of Consumers
}

\author{
Mohammad Hossein Moshref Javadi ${ }^{1}$, Hossein Rezaei Dolatabadi ${ }^{1}$, Mojtaba Nourbakhsh ${ }^{1}$, Amir Poursaeedi $^{1} \&$ \\ Ahmad Reza Asadollahi ${ }^{1}$ \\ ${ }^{1}$ Department of Management, University of Isfahan, Isfahan, Iran \\ Correspondence: Mojtaba Nourbakhsh, Department of Management, University of Isfahan, P.O. Box \\ 81589-43641, Isfahan, Iran. Tel: 98-913-169-1865. E-mail: Mojtaba2020@gmail.com
}

Received: June 29, 2012 Accepted: August 6, 2012 Online Published: September 10, 2012

doi:10.5539/ijms.v4n5p81 URL: http://dx.doi.org/10.5539/ijms.v4n5p81

\begin{abstract}
The purpose of this study is to analyze factors affecting on online shopping behavior of consumers that might be one of the most important issues of e-commerce and marketing field. However, there is very limited knowledge about online consumer behavior because it is a complicated socio-technical phenomenon and involves too many factors. One of the objectives of this study is covering the shortcomings of previous studies that didn't examine main factors that influence on online shopping behavior. This goal has been followed by using a model examining the impact of perceived risks, infrastructural variables and return policy on attitude toward online shopping behavior and subjective norms, perceived behavioral control, domain specific innovativeness and attitude on online shopping behavior as the hypotheses of study. To investigate these hypotheses 200 questionnaires dispersed among online stores of Iran. Respondents to the questionnaire were consumers of online stores in Iran which randomly selected. Finally regression analysis was used on data in order to test hypothesizes of study. This study can be considered as an applied research from purpose perspective and descriptive-survey with regard to the nature and method (type of correlation).

The study identified that financial risks and non-delivery risk negatively affected attitude toward online shopping. Results also indicated that domain specific innovativeness and subjective norms positively affect online shopping behavior. Furthermore, attitude toward online shopping positively affected online shopping behavior of consumers.
\end{abstract}

Keywords: online shopping, shopping behavior, consumer attitudes, perceived risks, B2C e-commerce

\section{Introduction}

In the business to consumer (B2C) e-commerce cycle activity, consumers use Internet for many reasons and purposes such as: Searching for product features, prices or reviews, selecting products and services through Internet, placing the order, making payments, or any other means which is then followed by delivery of the required products through Internet, or other means and last is sales service through Internet or other mean (Sinha, 2010). Over the past few decades, the Internet has developed into a vast global market place for the exchange of goods and services. In many developed countries, the Internet has been adopted as an important medium, offering a wide assortment of products with 24 hour availability and wide area coverage. In some other countries, such as Iran, however business-to-consumer electronic commerce has been much below than anticipated proportion of total retail business due to its certain limitations (Sylke, Belanger, and Comunale, 2002). Also, E-commerce has become an irreplaceable marketing channel in business transactions. Online stores and services are important sales channels in B2C transactions. Studying online shopping behavior of consumers has been one of the most important research agendas in e-commerce during the past decade (Chen, 2009). The research of online consumer behavior has been conducted in multiple disciplines including information systems, marketing, management science, psychology and social psychology, etc. (Hoffman and Novak, 1996; Koufaris, 2002; Gefen et al., 2003; Pavlou, 2003, 2006; Cheung et al., 2005; Zhou et al, 2007).

Online shopping behavior (also called online buying behavior and Internet shopping/buying behavior) refers to the process of purchasing products or services via the Internet. The process consists of five steps similar to those associated with traditional shopping behavior (Liang and Lai, 2000). In the typical online shopping process, when potential consumers recognize a need for some merchandise or service, they go to the Internet and search 
for need-related information. However, rather than searching actively, at times potential consumers are attracted by information about products or services associated with the felt need. They then evaluate alternatives and choose the one that best fits their criteria for meeting the felt need. Finally, a transaction is conducted and post-sales services provided. Online shopping attitude refers to consumers' psychological state in terms of making purchases on the Internet (Li and Zhang, 2002).

Although many studies examined various factors affecting on online shopping behavior independently, most of them isolated a few major factors, usually between three and six factors (Chen, 2009). The drawback of ignoring some factors is that the compound effects resulted from the interactions among the factors included in the research and those not included are often ignored and missing, which thus leads to the findings to be lack of generalizability.

This study attempts to develop such a research to study the effects of several major factors which are identified by prior studies on online shopping behavior. The research questions are thus stated as followed.

1) How do perceived Risks (Financial risks, product risk, convenience risk and non-delivery risk) impact attitude toward online shopping?

2) How do infrastructural variables and easy and convenient return policy impact attitude toward online shopping?

3) How do subjective norms, Perceived behavioral control and domain specific innovativeness impact online consumer behavior?

4) How does the attitude impact online consumer behavior?

The finding of this research offer a more comprehensive understanding of online consumer behavior by identifying the compound effects of various external behavioral beliefs, attitude, intentions and perceived risks, social influence, etc. Specifically, the findings provides in-depth insight into what factors drive online consumers most, how they work and what are their implications for consumers and e-commerce vendors. The findings also further confirm some previous research results and help clarify and explain the inconsistent conclusions from prior studies in the area. In general, this study enriches our knowledge of online shopping behavior from the behavioral perspective.

To meet the objectives of the research, first, we begin with a review of the literature on online shopping and factors affecting consumers' shopping behavior. This is followed by an outline of the methodological approach and the results of the study are reported. Finally, the conclusion and managerial implications are discussed.

\section{Theoretical Background}

Various studies have used some known theories to explain the online shopping behavior. Prior research has shown that there are many factors that affect online consumer behavior, but a complete coverage of all potential factors in one research model is almost impossible. Most studies focused on a few major factors. For example, Koufaris (2002) tested factors which come from information systems (technology acceptance model), marketing (Consumer Behavior), and psychology (Flow and Environmental Psychology) in one model; Pavlou (2003) studied interrelationships between consumer acceptance of e-commerce and trust, risk, perceived usefulness, and perceived ease of use. Pavlou and Fygenson (2006) examined consumer's adoption of e-commerce with the extended theory of planned behavior (TPB) (Ajzen, 1991). In their research model, consumer behavior was separately examined in terms of getting information behavior and purchasing behavior, both of which were influenced by trust and perceived risk, consumer's attitude, social influence, personal online skills, and technology-oriented factors including perceived usefulness, perceived ease of use and web site features. Also, previous researches have revealed that online buying behavior is affected by demographics, channel knowledge, perceived channel utility and shopping orientations (e.g., Li, Cheng, and Russell, 1999; Weiss, 2001). Results indicate that compared with brick-and-mortar shoppers, online consumers tend to be older (Bellman et al., 1999; Donthu and Garcia, 1999; Weiss, 2001), better educated (Bellman et al., 1999; Li et al., 1999; Swinwyard and Smith, 2003), have higher income (Bellman et al., 1999; Li et al., 1999; Donthu and Garcia, 1999; Swinwyard and Smith, 2003), and more technologically savvy (Li et al., 1999; Swinwyard and Smith, 2003). Men are more likely to purchase products and/or services from the Internet than women (Garbarino and Strahilevitz, 2004; Korgaonkar and Wolin, 1999; Slyke et al., 2002). Reasons for shopping online have been cited for time efficiency, avoidance of crowds, and 24 hour shopping availability (Karayanni, 2003). 


\section{Literature Review}

\subsection{Online Shopping and Online Stores}

Compared to physical stores, online stores have many advantages: They are convenient and time saving and no more traveling and waiting in lines is needed. They are open in all time and they are accessible anytime and anywhere. These stores provide consumers with free and rich information about products and services. They also have some online tools to help consumers compare and make purchase decisions among various products and services. Hoffman and Novak (1996) indicated that interactivity is the key distinguishing feature between marketing communication on the Internet and traditional mass media. Today online consumers have more control and bargaining power than consumers of physical stores because the Internet offers more interactivities between consumers and product/service providers as well as greater availability of information about products and services. Geissler and Zinkhan (1998) claimed that the Internet shifted the balance of power in favor of consumers as it became very easy for them to make shopping comparisons and evaluate alternatives without being pressured by salespeople. Online stores reduce transaction costs and have advantage for both consumers and vendors.

However, online stores also have disadvantages compare to brick-and-mortar stores. In online stores customers can't have any sense about the product they see in the internet (seeing, touching, tasting, smelling, and hearing) as they search for and purchase products. In online stores, consumers may develop low trust and perceive elevated risk highly because of the lack of face-to-face communication. Although this difficulty can be reduced by using certain software tools such as the online recommendation agent (Häubl and Murray, 2003; Xiao and Benbasat, 2007) and the online negotiation agent (Huang and Sycara, 2002; Huang and Lin, 2007).

\subsection{Perceived Risks}

Perceived risk refers to the nature and amount of risk perceived by a consumer in contemplating a particular purchase decision (Cox and Rich, 1964). Before purchasing a product, a consumer considers the various risks associated with the purchase. The different types of risks are referred to as perceived or anticipated risks. Research suggests that consumers generally prefer to use electronic commerce for purchasing products that do not require physical inspection (Peterson et al., 1997). The higher the perceived experience risk, the consumer may shift to brick-and-mortar retailer for the purchase of the product. Whereas, the lower the perceived risk, the higher the propensity for online shopping (Tan, 1999). Risks perceived or real, exist due to technology failure (e.g., breaches in the system) or human error (e.g., data entry mistakes). The most frequently cited risks associated with online shopping include financial risk (e.g., is my credit card information safe?), product risk (e.g., is the product the same quality as viewed on the screen?), convenience (e.g., Will I understand how to order and return the merchandise?), and non-delivery risk (e.g., What if the product is not delivered?) The level of uncertainty surrounding the online purchasing process influences consumers' perceptions regarding the perceived risks (Bhatnagar et al., 2000).

\subsection{Attitude}

Since the mid-1970s, the study of consumer's attitudes has been associated with consumer purchasing behavior research. According to the model of attitude change and behavior (e.g., Fishbein and Ajzen, 1975), consumer attitudes are affected by intention. When this intention is applied to online shopping behavior, the research can examine the outcome of the purchase transaction. Attitude is a multi-dimensional construct. One such dimension is the acceptance of the Internet as a shopping channel (Jahng, Jain, and Ramamurthy, 2001). Previous research has revealed attitude towards online shopping is a significant predictor of making online purchases (Yang et al., 2007) and purchasing behavior (George, 2004; Yang et al., 2007).

\subsection{Perceived Behavioral Control}

Ajzen and Madden (1986) extended the TRA into the Theory of Planned Behavior (TPB) by adding a new construct "perceived behavioral control" as a determinant of both intention and behavior. Perceived behavioral control refers to consumers' perceptions of their ability to perform a given behavior. TPB allows the prediction of behaviors over which people do not have complete volitional control. Perceived behavioral control reflects perceptions of internal constraints (self-efficacy) as well as external constraints on behavior, like availability of resources. It has been found that the Planned Behavioral Control (PBC) directly affects online shopping behavior (George, 2004) and has a strong relationship with actual Internet purchasing (Khalifa and Limayem, 2003).

\subsection{Domain Specific Innovativeness}

Domain Specific Innovativeness (DSI) is "the degree to which an individual is relatively earlier in adopting an innovation than other members of his system" (Rogers and Shoemaker 1971, p. 27). For the most part, people 
like continuity in their daily lives, including in their shopping routine. While the Internet and online shopping offers consumers a wide breadth and depth of product offerings, it also requires them to go outside their normal shopping routine. Online shoppers need to learn new technology skills in order to search, evaluate and acquire products. Consumers who prefer brick-and-mortar shopping over other retail channels do not perceive the online shopping as a convenience (Kaufman-Scarborough and Lindquist, 2002). Research has revealed that online shopping innovativeness is a function of attitude towards the online environment and individual personal characteristics (Midgley and Dowling, 1978; Eastlick, 1993; Sylke, Belanger, and Comunale, 2004; Lassar et al., 2005). Innovative consumers are more inclined to try new activities (Robinson, Marshall and Stamps, 2004; Rogers, 1995). Adoption of online shopping is depiction of individual's innovative characteristic (Eastlick, 1993). Adopting a new technology is a function of one's attitude towards it (Moore and Benbasat, 1991). It is expected that person's domain specific innovativeness has a propensity to shop online.

\subsection{Subjective Norms}

In order to be successful retailers must understand consumers' purchasing behaviors. This is particularly true for online retailers. A comprehensive understanding must be made of the website's design and support in order to match its consumers' information gathering and purchasing behaviors. The visual stimuli and communication through text and sound can positively or negatively affect consumers' online desires and actions (Vijayasarathy and Jones, 2000).

The Theory of Reasoned Action (TRA) (Azjen and Fishbein, 1980) has successfully been used to explain human behavior. The theory proposes that human behavior is preceded by intentions, which are formed based on consumers' attitude toward the behavior and on perceived subjective norms. Attitude reflects the individual's favorable or unfavorable feeling towards performing a behavior. Subjective norms capture the consumers' perceptions of the influence of significant others (e.g., family, peers, authority figures, and media). It is related to intention because people often act based on their perception of what others think they should be doing. Subjective norms tend to be more influential during early stages of innovation implementation when users have limited direct experience from which to develop attitudes (Taylor and Todd, 1995). It is during this stage of attitudinal development that online retailers can influence shoppers' propensity for purchasing behaviors (Yu and $\mathrm{Wu}, 2007)$.

\section{Background of Research}

Barnes and Guo (2011) in a study "Purchase behavior in virtual worlds: An empirical investigation in Second Life" developed and tested a conceptual model of purchase behavior in virtual worlds using a combination of existing and new constructs. They examined a kind of shopping behavior that consumers spend noticeable amount of money for shopping from internet. Factors of their model were external motivators like perceived value, instinct motivators like perceived happiness, social factors and consumers' habits. The result of study indicated that one's habits, external and instinct motivators have great effect on shaping online shopping behavior of them.

Herna'ndez et al. (2011) in a study "Age, gender and income: do they really moderate online shopping behavior?" Analyzed whether individuals' socioeconomic characteristics - age, gender and income - influence their online shopping behavior. The individuals analyzed are experienced e-shoppers i.e. individuals who often make purchases on the internet. The results of their research show that socioeconomic variables moderate neither the influence of previous use of the internet nor the perceptions of e-commerce; in short, they do not condition the behavior of the experienced e-shopper.

Chen (2009) in his dissertation entitled "Online consumer behavior: an empirical study based on theory of planned behavior " extends theory of planned behavior (TPB) by including ten important antecedents as external beliefs to online consumer behavior. The results of data analysis confirm perceived ease of use (PEOU) and trust are essential antecedents in determining online consumer behavior through behavioral attitude and perceived behavioral control. The findings also indicate that cost reduction helps the consumer create positive attitude toward purchase. Further, the findings show the effects of two constructs of flow -concentration and telepresence, on consumers' attitude. Concentration is positively related to attitude toward purchase, but telepresence likely decreases attitude due to the consumers' possible nervousness or concern about uncertainty in the online environment.

Demangeot and Broderick (2007) in a research entitled "Conceptualizing consumer behavior in online shopping environments", seek to adopt a holistic approach to consider how consumers perceive online shopping environments. The conceptual model proposes that consumers perceive these environments in terms of their sense-making and exploratory potential, and it considers the influence of these on user involvement with the web 
site, shopping value and intention to revisit Findings indicate that sense-making and exploratory potential are distinct constructs; exploratory potential mediates the relationship between sense-making potential and involvement. Furthermore, involvement is essential in producing shopping value and intention to revisit.

Ying (2006) in his study "Essay on modeling consumer behavior in online shopping environments" examined online purchase behavior across multiple shopping sessions. Shopping cart abandonment is the bane of many e-commerce websites. He investigated abandoned shopping carts in an online grocery shopping setting. Specifically, he developed a joint model for the cart, order, and purchase quantity decisions. The interdependence between the three decisions is captured by the correlations between the error terms. Empirical analysis shows that not all abandoned shopping carts result in lost sales. Customers routinely pick up abandoned carts and complete the final orders. Among the factors that propel customers to continue with aborted shopping are the time of shopping, time elapsed since the previous visit, the number of items left in the abandoned cart, and promotion intensity. The study offers marketers important managerial implications on how to mitigate the shopping cart abandonment problem.

Khalifa and Limayem (2003) in a research entitled "Drivers of internet shopping" applied well-established behavioral theories to explain Internet consumer behavior. Then, they conducted a longitudinal survey study to identify key factors influencing purchasing on the Web and to examine their relative importance. The results indicate that the intentions of Internet consumers are significantly affected by the perceived consequences of online shopping, the consumers' attitudes towards it, and social influence.

Kim and Park (2003) in a study "Identifying key factors affecting consumer purchase behavior in an online shopping context" investigated the relationship between various characteristics of online shopping and consumer purchase behavior. Result of the online survey with 602 Korean customers of online bookstores indicate that information quality, user interface quality and security perceptions affect information satisfaction and relational benefit that in turn, are significant related to each consumers' site commitment and actual purchase behavior.

\section{Conceptual Model}

The model which used in this article was developed to examine the online shopping behaviors of Iranian consumers. This model examines (1) the relationship between perceived risks, return policy, service, infrastructural variables and attitudes towards online shopping and (2) the influence of an individual's domain specific innovativeness (DSI), attitude, subjective norm and planned behavior (PBC) toward online shopping.

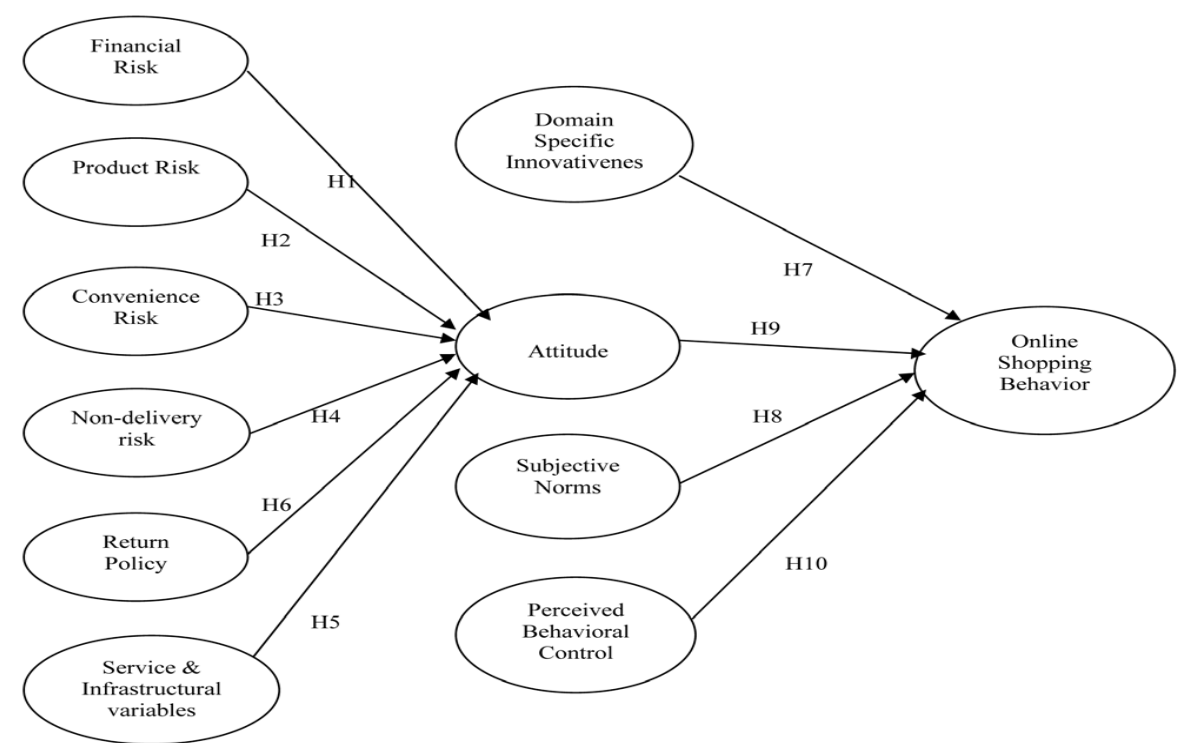

Figure 1. Conceptual model 


\section{Methodology}

\subsection{Overview}

The purpose of this study is analyzing factors affecting online shopping behavior of consumers in Iran. This goal has been followed by examining the effect of perceived risks, service and infrastructural variables and return policy on attitude toward online shopping, impact of domain specific innovativeness, subjective norms perceived behavioral control and attitude toward online shopping on shopping behavior as the hypotheses of the study.

Independent variables in this study are as follows:

- $\quad$ Financial risks

- Product risks

- Convenience risk

- Non-delivery risk

- Infrastructural variables

- Return policy

- Attitude

- Subjective norms

- Perceived behavioral control

- Domain specific innovativeness

Dependent variables are:

- Attitude

- Online shopping behavior

For testing hypotheses of the study, regression analysis was used. Using this method requires some prerequisites that are:

1). There should not be correlation between errors, means errors should be independent.

2). Errors should have normal distribution.

In order to check independence between errors, Durbin-Watson test was used. The DW value should be between 1.5 and 2.5 to reject correlation between errors. For all hypothesis of this study two above conditions were tested and for all of the hypotheses they were satisfied. By the way, for all hypotheses, Durbin-Watson values were between 1.5 and 2.5 and means errors are independent.

\subsection{Sampling and Measurement}

To test the main hypothesis of this research, we conducted a questionnaire (See Appendix A). This questionnaire that adopted and combined from many similar researches, used to collect required data in order to support or reject hypotheses (See table 1). The questionnaires dispersed among 5 big online stores of Iran, randomly. This questionnaire assessed all variables of conceptual model via 51 questions. The reliability of questions was tested by Cronbach's Alpha and result showed that all of them were above 0.7 offering good reliability of the questionnaire which was conducted by investigating previous researches and experts' suggestions. All questions were rated on a seven-point Likert scale from "strongly disagree" (1) to "strongly agree" (7). At first, an online store was randomly selected and 30 questionnaires were sent for the consumers that had shopping from that online store. By analyzing the data achieved by these consumers, standard deviation of society identified by using Cochran's formula for unlimited society, the formula turned 120 as the quantity of sample. 
Table 1. Adoption of questions details

\begin{tabular}{|c|c|c|c|}
\hline Source & Variable & Question no. & Section no. \\
\hline $\begin{array}{c}\text { Forsythe et al. (2006), } \\
\text { Karayanni (2003) } \\
\text { Swinyard \& Smith (2003) } \\
\text { Liang \& Huang (1998) }\end{array}$ & Online shopping behavior & 1 to 17 & Section 1 \\
\hline $\begin{array}{l}\text { Swinyard \& Smith (2003) } \\
\text { Forsythe et al. (2006) }\end{array}$ & Financial Risk & 1 to 3 & Section 2 \\
\hline $\begin{array}{l}\text { Swinyard \& Smith (2003) } \\
\text { Forsythe et al. (2006) }\end{array}$ & Product Risk & 4 to 6 & \\
\hline $\begin{array}{l}\text { Swinyard \& Smith (2003) } \\
\text { Forsythe et al. (2006) }\end{array}$ & Convince Risk & 7 to 12 & \\
\hline Forsythe et al. (2006) & Non-delivery Risk & 13 and 14 & \\
\hline Lewis (2006) & Return Policy & 15 to 17 & \\
\hline Lewis (2006) & Infrastructural Variables & 18 to 20 & \\
\hline George (2004) & Attitude & 1 and 2 & Section 3 \\
\hline $\begin{array}{c}\text { George (2004) } \\
\text { Swinyard \& Smith (2003) }\end{array}$ & Subjective Norms & 3 to 6 & \\
\hline $\begin{array}{c}\text { George (2004) } \\
\text { Forsythe et al. (2006) }\end{array}$ & Perceived Behavioral Control & 7 to 10 & \\
\hline $\begin{array}{c}\text { George (2004) } \\
\text { Lassar et al. (2005) }\end{array}$ & Domain Specific Innovativeness & 11 to 14 & \\
\hline
\end{tabular}

\subsection{Data Collection}

200 electronic questionnaires were sent randomly among consumers of 5 big online stores in Iran by email. There were two main groups among these consumers: consumers that purchase and consumers who do not purchase. We sent questionnaire for both groups. Finally 107 questionnaires were usable for analyzing. Respondents were $44.9 \%$ female and $55.1 \%$ male (see Table 2). Also, this study was done from February, 2012 to June, 2012.

Table 2. Demographic profile of participants $(n=107)$

\begin{tabular}{lll}
\hline Variable & Frequency & Percentage \\
\hline Age & & \\
Less than 21 & 2 & 1.9 \\
$21-29$ & 70 & 65.4 \\
$30-39$ & 31 & 29 \\
40 and above & 4 & 3.7 \\
Gender & & \\
Men & 59 & 55.1 \\
Women & 48 & 44.9 \\
Education & & \\
Lower than high school diploma & 7 & 7 \\
High school diploma and Associates degree & 13 & 12 \\
Bachelor's degree & 32 & 30 \\
Master's degree or higher & 55 & 51 \\
\hline
\end{tabular}




\section{Data Analysis and Results}

In order to test the study's hypotheses, a series of regressions were used to analyze the relationships between the predictors (independent variables) and the dependent variables. The hypotheses and results are as follows:

Hypothesis 1: the risk of losing money and financial details will have negative effect on attitude toward online shopping.

Hypothesis 2: The product risk will have negative effect on attitude towards online shopping.

Hypothesis 3: Having a friendly website and good service to better help the customers for shopping, will have positive influence on attitude towards shopping online

Hypothesis 4: Fear of non-delivery of order will have negative influence on attitude towards shopping online.

Among perceived risks, effects of financial risks and non-delivery risk on attitude were significant at the 0.05 level. Thus, $H 1$ and $H 4$ are fully supported (See Table 3 And 6). But $H 2$ and $H 3$ were not significant at the 0.05 level and are not supported. (See Table 4 and 5).

Table 3. Regressions of determinants of attitude toward online shopping ( 2 items, $\alpha=0.720$ )

\begin{tabular}{|c|c|c|c|c|c|}
\hline Predictor & items & $\alpha$ & $\mathrm{B}$ & t-value & $p$-value \\
\hline Financial Risk & 3 & 0.882 & -0.181 & -2.128 & $0.036^{* *}$ \\
\hline
\end{tabular}

Table 4. Regressions of determinants of attitude toward online shopping ( 2 items, $\alpha=0.720$ )

\begin{tabular}{llllll}
\hline Predictor & items & $\alpha$ & $\mathrm{B}$ & $\mathrm{t}$-value & $\mathrm{p}$-value \\
\hline Product Risk & 3 & 0.819 & -0.080 & -0.734 & $0.465^{* *}$ \\
\hline Notes: & Denotes significance at the 0.05 level & & & &
\end{tabular}

Table 5. Regressions of determinants of attitude toward online shopping ( 2 items, $\alpha=0.720$ )

\begin{tabular}{|c|c|c|c|c|c|}
\hline Predictor & items & $\alpha$ & $\mathrm{B}$ & t-value & p-value \\
\hline Convenience Risk & 6 & 0.795 & -0.148 & -1.287 & $0.201 * *$ \\
\hline
\end{tabular}

Table 6. Regressions of determinants of attitude toward online shopping ( 2 items, $\alpha=0.720$ )

\begin{tabular}{|c|c|c|c|c|c|}
\hline Predictor & items & $\alpha$ & $\mathrm{B}$ & t-value & $\mathrm{p}$-value \\
\hline Non-delivery Risk & 2 & 0.719 & -0.227 & -2.546 & $0.012 * *$ \\
\hline
\end{tabular}

Hypothesis 5: After sales service, cyber laws and low shipping fees or free delivery will have positive influence on attitude towards online shopping.

Hypothesis 6: Convenient product return policy will have positive effect on attitude towards shopping online.

Effect of infrastructural variables and return policy on attitude was not significant at the 0.05 level and is not supported, so $H 5$ and $H 6$ are rejected (See Table 7 and 8).

Table 7. Regressions of determinants of attitude toward online shopping ( 2 items, $\alpha=0.720$ )

\begin{tabular}{lllllll}
\hline & Predictor & items & $\alpha$ & $\mathrm{B}$ & t-value & $\mathrm{p}$-value \\
\hline Return Policy & 3 & 0.897 & -0.140 & -1.563 & $0.121^{* *}$ \\
\hline Notes: & $* *$ & Denotes significance at the 0.05 level & & & &
\end{tabular}

Table 8. Regressions of determinants of attitude toward online shopping ( 2 items, $\alpha=0.720$ )

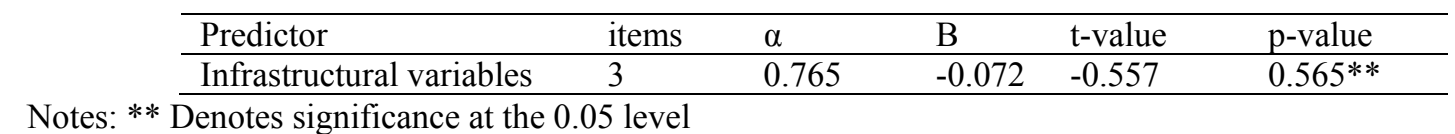

Notes: ** Denotes significance at the 0.05 level 
Hypothesis 7: Early adopter of technology and products will have positive effect on online shopping behavior.

Hypothesis 8: Family members, friends and peers' online experience and suggestions will positively influence online buying behavior.

Hypothesis 9: Attitude of consumers towards online shopping significantly affects their online shopping behavior.

Effect of domain specific innovativeness, subjective norms and attitude toward online shopping on online shopping behavior were significant at the 0.05 level. Thus, $H 7, H 8$ and $H 9$ are fully supported (see Table 9,10 and 11).

Table 9. Regressions of determinants of online shopping behavior (17 items, $\alpha=0.867$ )

\begin{tabular}{llllll}
\hline Predictor & items & $\alpha$ & $\mathrm{B}$ & $\mathrm{t}$-value & $\mathrm{p}$-value \\
\hline Attitude & 2 & 0.720 & 0.215 & 3.620 & $0.000^{* *}$ \\
\hline Notes: & $* *$ Denotes significance at the 0.05 level & & & &
\end{tabular}

Table 10. Regressions of determinants of online shopping behavior (17 items, $\alpha=0.867$ )

\begin{tabular}{|c|c|c|c|c|c|}
\hline Predictor & items & $\alpha$ & $\mathrm{B}$ & t-value & $\mathrm{p}$-value \\
\hline Subjective norms & 4 & 0.762 & 0.164 & 2.318 & $0.022 * *$ \\
\hline
\end{tabular}

Table 11. Regressions of determinants of online shopping behavior (17 items, $\alpha=0.867$ )

\begin{tabular}{llllll}
\hline Predictor & items & $\alpha$ & $\mathrm{B}$ & $\mathrm{t}$-value & $\mathrm{p}$-value \\
\cline { 2 - 7 } Domain specific innovativeness & 4 & 0.715 & 0.307 & 5.065 & $0.000^{* *}$ \\
\cline { 2 - 6 } & Denotes significance at the 0.05 level & & & &
\end{tabular}

Hypothesis 10: lack of facility to shop online will have negative effect on online shopping behavior.

Effect of perceived behavioral control on online shopping behavior is not significant at the 0.05 level and is not supported, so $H 10$ is rejected (See Table 12).

Table 12. Regressions of determinants of online shopping behavior (17 items, $\alpha=0.867$ )

\begin{tabular}{llllll}
\hline Predictor & items & $\alpha$ & B & t-value & -value \\
\hline Perceived behavioral control & 4 & 0.787 & 0.081 & 1.114 & $0.268^{* *}$ \\
\hline
\end{tabular}

Notes: $* *$ Denotes significance at the 0.05 level

\section{Discussion}

The results showed that $H 1$ and $H 4$ are significantly supported. Thus, fear of losing money and financial details has negative effect on attitude toward online shopping. Also the Fear of non-delivery of order will have negative influence on attitude towards shopping online. That is, the higher the risk of losing money and probability of disclosing credit card information, the lower attitude toward online shopping. This finding is compatible with findings of the Forsythe and Shi (2003) and Biswas and Biswas (2004). In these studies, financial risk is an important factor for not shopping online. Also the higher the probability of non-delivery of order, the lower attitude toward online shopping. It indicates that the non-delivery risk is a significant factor for affecting attitude and hence behavior towards shopping online. People do not tend to shop online because they are not sure whether the ordered merchandise will be delivered or not and lack of seriousness and efforts towards building trust by the retailers makes it a significant reason.

Results of testing the hypotheses $H 2$ and $H 3$ indicated that effect of product risks and convenience risk on attitude toward online shopping is not significant. Our findings are consistent with the findings from the previous study from Sinha (2010). This is also in contrast with the findings of the existing studies (e.g. Forsythe and Shi, 2003; Biswas and Biswas, 2004) where product and convenience risk are important significant risk factors for not shopping online. The possible reason of this insignificance in Iranian context appears to be the indifference and unwillingness of these shoppers towards online medium. 
Results of testing the hypotheses $H 5$ and $H 6$ indicated that infrastructural variables and return policy were not significant at the 0.05 level and are not supported. That is, the regression results with after sales service, cyber laws and shipping fees as independent variable and attitude toward online shopping as dependent variable does not show significant influence of these service and infrastructural factors on consumers' attitude towards online shopping and regression results on return policy doesn't shows significant influence on attitude towards online shopping.

Regression analysis on hypothesis $H 7$ showed significant influence of domain specific innovativeness (DSI) on online shopping behavior. That is the higher DSI, the higher effect on online shopping behavior. Results also supported the hypothesis $\mathrm{H} 8$ and H9. Accepting the hypothesis $\mathrm{H} 8$ means that the opinion of friends and peers will more likely influence consumers' online buying behavior. Also the mean response for subjective norm items is more than 4 means respondents were positively inclined towards making an online purchase if they get friends opinion on merchandise or when they see them shopping online. This finding is in sync with some studies Jarvelainen (2007) and Khalifa and Limayem (2003) where friends, relatives and media (Subjective Norm) has been an important factor influencing the online shopping behavior but not with others like Wang et.al (2007) where it subjective norm has not been significant. The possible reason of this is Iranian collective society. People like to go to market places together and value opinions of others.

Supporting the hypothesis $H 9$ indicated that attitude of consumers towards online shopping significantly affected their online shopping behavior. Thus when a consumer has a significant attitude toward online shopping, this will have effect on his/her shopping behavior.

Results of testing the hypotheses $H 10$ indicated that effect of PBC on online shopping is not significant. Our findings are consistent with the findings from the previous studies (Sinha, 2010).

\section{Conclusion}

In this study we examined some factors affecting on online shopping behavior of consumers. A conceptual model was used in order to assess the effects of variables on each other using regression analysis. Results of hypotheses testing indicated that financial risk and non-delivery risk has negative effect on attitude toward online shopping behavior. That is, e-retailers should make their website safer and assure customers for delivery of their products. has Positive effect attitude toward online shopping on online shopping behavior of consumers indicate that considering attitude variables make a substantial contribution in online shopping. Also, subjective norms have positive effect on shopping behavior. This means the more people suggest e-buying to each other, the more this buying method will be popular among people. This makes necessary the use of word of mouth marketing for retailers. Domain specific innovativeness has positive effect on online shopping behavior. This means that marketing specialists should target this society in their marketing strategy formulation for better effectiveness of their marketing program.

Every research has limitations. Limitations of this study are:

1) As we discussed before, there are many factors affecting on online shopping behavior. But in this study because of time constraints we didn't examined all factors influencing on online shopping behavior.

2) Because of using questionnaire as data gathering tools, the respondents may not answer the questions exactly according to what they think and behave.

3) In this research because of time and cost constraints we examined factors affecting on online shopping behavior of consumers in Iran. It is obvious that is other countries people have different characteristics and behaviors. Then result of this study may have lack of generalizability to other countries.

4) Statistical society of this study was online stores selling electronic goods. So development of statistical society to other stores with different products and services decrease the limitation of study.

5) The methodology of this study for analyzing the data may not be able to fully assess the online shopping behavior of consumers based on discussed variables.

For future studies, authors suggest that:

1) In this research four factors have only been tested on online shopping behavior. Researchers can examine other factors affecting on online shopping behavior with extensive researches.

2) By extending this study to other countries, we can reach to better results and understanding about online shopping behavior of people. 
3) We used only 5 online stores for our statistical society. By assessing better sites like Amazon.com we can reach to better and more reliable society for research.

4) Including cultural factors in model could show better dimension of online shoppers.

\section{Managerial Implications}

Based on the results and findings, this study identifies the following implications. First, based on the results and findings of this study, retail companies should start taking measures to eliminate risk factor and build trust in this form of retail. The retail managers should sway consumers through different platforms like social networking sites, ads, promotions, online only discounts etc. to let people cross the threshold and start buying because Iranian consumers are still comfortable with brick and mortar format as they appreciate friendly approach of salesman and social element of shopping, which has been found as important element in shopping (Tauber, 1972). In addition, they need to make website user- friendly and less intriguing. It should encourage online consumers to spend time exploring the site and comparing prices online, provide detail product information and member discounts The results also suggest that after-sales operations like, dispute settling and delivery, should be carried out promptly and quickly so that consumer would build faith in the system. During the process of purchasing, online agents can help customers and simplify the purchasing procedure to give a feeling of friendliness of salesman or demonstrate how to purchase with clear text, images or examples.

Second, because of perceived lack of secured transaction (financial risk), retailers should introduce a mechanism that would improve safety and privacy to motivate people to buy online. Customers should not be worry about losing their financial details and their credit card information. Using SSL protocol for payment pages will secure the web page from disclosure of credit card information.

Third, the impact of subjective norms on online shopping behavior proposes that online retailers should use word-of-mouth marketing to for getting their website known to consumers. This method could be one of the most effective method among other tools and methods of advertising.

Finally, based on the study's results that consumers were worried and unsure about delivery of their orders (non-delivery risk), online retailers should provide the insurance for shoppers that they ordered items and make sure that the products will definitely be delivered to them. They can achieve this goal by providing certain certificate from authorities and governmental organizations that allow them to sell goods from internet and assure customers that this online retailer is rendering the job legally, so customers will buy from them with more confident and will not be worry about the delivery of their orders anymore.

\section{References}

Ajzen, I. (1991). The theory of planned behavior. Organizational Behavior and Human Decision Processes, 50 , 179-211. http://dx.doi.org/10.1016/0749-5978(91)90020-T

Ajzen, I., \& Fishbein. M. (1980). Understanding attitudes and predicting social behavior. New Jersey, Englewood Cliffs, Prentice-Hall.

Ajzen. I., \& Madden, T. J. (1986). Prediction of Goal-Directed Behavior: Attitudes, Intentions, and Perceived Behavioral Control. Journal of Experimental Social Psychology, 22, 453-474. http://dx.doi.org/10.1016/0022-1031(86)90045-4

Barnes, S., \& Guo, Y. (2011). Purchase behavior in virtual worlds: an empirical study in second life. Information \& Management, 48(7), 303-312. http://dx.doi.org/10.1016/j.im.2011.07.004

Bellman, S., Lohse, G. L., \& Johnson, E. J. (1999). Predictors of Online Buying Behavior. Communications of the ACM, 4(12), 32-38. http://dx.doi.org/10.1145/322796.322805

Bhatnagar, A., Misra, S., \& Rao, H. R. (2000). On Risk, Convenience and Internet Shopping Behavior. Communications of the ACM, 48(2), 98-105. http://dx.doi.org/10.1145/353360.353371

Biswas, D., \& Biswas, A. (2004). Perceived risks in online shopping: Do Signals matter more on the web? Journal of Interactive Marketing, 18(3), 30-45. http://dx.doi.org/10.1002/dir.20010

Chen, L. (2009). Online consumer behavior: An empirical study based on theory of planned behavior. Doctoral dissertation, University of Nebraska.

Cheung, C. M. K., Chan, G. W. W., \& Limayem, M. (2005). A critical review of online consumer behavior: Empirical research. Journal of Electronic Commerce in Organizations, 3(4), 1-19. http://dx.doi.org/10.4018/jeco.2005100101 
Cox, D. F., \& Rich, S. J. (1964). Perceived Risk and Consumer Decision - Making: The case of Telephone Shopping. Journal of Marketing Research, 1(4), 32-39. http://dx.doi.org/10.2307/3150375

Demangeot, C., \& Broderick, A. J. (2007). Conceptualizing consumer behavior in online shopping environments. International Journal of Retail and Distribution Management, 35(11), 878 - 894. http://dx.doi.org/10.1108/09590550710828218

Donthu, N., \& Garcia, A. (1999). The Internet Shopper. Journal of Advertising Research, 39(3), 52-58.

Eastlick, M. (1993). Predictors of videotext adoption. Journal of Direct Marketing, 7, 66-74. http://dx.doi.org/10.1002/dir.4000070309

Fishbein, M., \& Ajzen, I. (1975). Belief, Attitude, Intention and Behavior: An Introduction to Theory and Research. Massachusetts, Addison-Wesley.

Forsythe, S. M., \& Shi, B. (2003). Consumer patronage and risk perceptions in Internet shopping. Journal of Business Research, 56(11), 867-875. http://dx.doi.org/10.1016/S0148-2963(01)00273-9

Garbarino, E., \& Strahilevitz, M. (2004). Gender differences in the perceived risk of buying online and the effects of receiving a site recommendation. Journal of Business Research, 57, 768-775. http://dx.doi.org/10.1016/S0148-2963(02)00363-6

Gefen, D., Karahanna, E., \& Straub, D. W. (2003). Trust and TAM in online shopping: An integrated model. MIS Quarterly, 27(1), 51-90.

Geissler, G. L., \& Zinkhan, G. M. (1998). Consumer perceptions of the World Wide Web: An exploratory study using focus group interviews. Advances in Consumer Research, 25(1), 386-392.

George, J. F. (2004). The theory of planned behavior and Internet purchasing. Journal of Internet Research, 14(3), 198-212. http://dx.doi.org/10.1108/10662240410542634

Häubl, G., \& Murray, K. B. (2003). Preference construction and persistence in digital marketplaces: The role of electronic recommendation agents. Journal of Consumer Psychology, 13(1), 75-91. http://dx.doi.org/10.1207/153276603768344807

Hernández, B., Jiménez, J., \& Martín, J. (2011). Age, gender and income: do they really moderate online shopping behavior? Online Information Review, 35(1), 113-133. http://dx.doi.org/10.1108/14684521111113614

Hoffman, D. L., Novak, T. P., \& Peralta, M. (1999). Building Consumer's Trust Online. Communication of the ACM, 42(4), 80-85. http://dx.doi.org/10.1145/299157.299175

Huang, P., \& Sycara, K. (2002). A computational model for online agent negotiation. System Sciences Proceedings of the 35th Hawaii International Conference, Hawaii.

Huang, S., \& Lin, F. (2007). The design and evaluation of an intelligent sales agent for online persuasion and negotiation. Electronic Commerce Research and Applications, 6(3), 285-296. http://dx.doi.org/10.1016/j.elerap.2006.06.001

Jahng, J., Jain, H., \& Ramamurthy, K. (2001). The impact of electronic commerce environment on user behavior. E-service Journal, 1(1), 41-53. http://dx.doi.org/10.2979/ESJ.2001.1.1.41

Jarvelainen, J. (2007). Online Purchase Intentions: An Empirical Testing of a Multiple-Theory Model. Journal of Organizational Computing, 17(1), 53-74.

Karayanni, D. A. (2003). Web-shoppers and non-shoppers: Compatibility, relative advantage and demographics. European Business Review, 15(3), 141-152. http://dx.doi.org/10.1108/09555340310474640

Kaufman-Scarborough, C., \& Lindquist, John, D. (2002). E-shopping in a multiple channel environment. Journal of Consumer Marketing, 19(4), 333-350. http://dx.doi.org/10.1108/07363760210433645

Khalifa, M., \& Limayem, M. (2003). Drivers of internet shopping. Communications of the ACM, 46(12), 233-239. http://dx.doi.org/10.1145/953460.953505

Kim, Y., \& Park, C. (2003). Identifying key factors affecting consumer purchase behavior in an online shopping context. International Journal of Retail and Distribution management, 31(1), 16-29. http://dx.doi.org/10.1108/09590550310457818

Korgaonkar, P. K., \& Wolin, L. D. (1999). A multivariate analysis of web usage. Journal of Advertising Research, 39(2), 53-68. 
Koufaris, M. (2002). Applying the technology acceptance model and flow theory to online consumer behavior. Information Systems Research, 13(2), 205-223. http://dx.doi.org/10.1287/isre.13.2.205.83

Lassar, W. M., Manolis, C., \& Lassar, S. S. (2005). The relationship between consumer innovativeness, personal characteristics, and online banking adoption. International Journal of Bank Marketing, 23(2), 176-199. http://dx.doi.org/10.1108/02652320510584403

Lewis, M. (2006). The effect of shipping fees on customer acquisition, customer retention, and purchase quantities. Journal of Retailing, 82(1), 13-23. http://dx.doi.org/10.1016/j.jretai.2005.11.005

Li, H., Kuo, C., \& Russell, M. G. (1999). The impact of perceived channel utilities, shopping orientations, and demographics on the consumer's online buying behavior. Journal of Computer-Mediated Communication, $5(2), 1-20$.

Li, N., \& Zhang, P. (2002). Consumer online shopping attitudes and behavior: An assessment of research. Information Systems proceedings of Eighth Americas Conference.

Liang, T., \& Lai, H. (2000). Electronic store design and consumer choice: an empirical study. System Sciences Proceedings of $33^{\text {rd }}$ International Conference in Hawaii.

Midgley, D. F., \& Dowling, G. R. (1978). Innovativeness: the concept and its measurement. Journal of Consumer Research, 4(4), 229-235. http://dx.doi.org/10.1086/208701

Moore, G. C., \& Benbasat, I. (1991). Development of an Instrument to Measure the perceptions of adopting an Information Technology Innovation. Information Systems Research, 2(3), 192-222. http://dx.doi.org/10.1287/isre.2.3.192

Nelson, P. (1970). Information and Consumer Behavior. Journal of Political Economy, 78(2). http://dx.doi.org/10.1086/259630

Pavlou, P. A. (2003). Consumer acceptance of electronic commerce: Integrating trust and risk with the technology acceptance model. International Journal of Electronic Commerce, 7(3), 69-103.

Pavlou, P. A., \& Fygenson, M. (2006). Understanding and predicting electronic commerce adoption: An extension of the theory of planned Behavior. MIS Quarterly, 30(1), 115-143.

Peterson, R. A., Balasubramanian, S., \& Bronnenberg, B. J. (1997). Exploring the implications of the Internet for consumer marketing. Journal of the Academy of Marketing Science, 25, 329-46. http://dx.doi.org/10.1177/0092070397254005

Robinson, L., Marshall, G. W., \& Stamps, M. B. (2005). Sales force use of technology: antecedents to technology acceptance. Journal of Business Research, 58(12), 1623-1631. http://dx.doi.org/10.1016/j.jbusres.2004.07.010

Rogers, E. M., \& Shoemaker, F. F. (1971). Communication of Innovations. New York, NY: The Free Press.

Sinha, J. (2010). Factors affecting online shopping behavior of Indian consumers. Doctoral dissertation, University of South Carolina, USA.

Swinyard, W. R., \& Smith, S. M. (2003). Why People Don't Shop Online: A Lifestyle Study of the Internet Consumers. Psychology and Marketing, 20(7), 567-597. http://dx.doi.org/10.1002/mar.10087

Sylke, V. C., Belanger F., \& Comunale, C. L. (2002). Gender differences in perceptions of Web-based shopping. Communications of the ACM, 45(8), 82-86. http://dx.doi.org/10.1145/545151.545155

Sylke, V. C., Belanger, F., \& Comunale, C. L. (2004). Factors influencing the adoption of web-based shopping: the impact of trust. ACM SIGMIS database, 35(2), 32-49. http://dx.doi.org/10.1145/1007965.1007969

Tan, S. J. (1999). Strategies for reducing consumer's risk aversion in Internet shopping. Journal of Consumer Marketing, 16(2), 163-178. http://dx.doi.org/10.1108/07363769910260515

Tauber, E. M. (1972). Why do people shop? Journal of Marketing, 36, 46-49. http://dx.doi.org/10.2307/1250426

Taylor, S., \& Todd, P. A. (1995). Assessing IT Usage: The Role of Prior Experiences. MIS Quarterly, 19(3), 561-570. http://dx.doi.org/10.2307/249633

Vijaysarathi, L., \& Jones, J. M. (2000). Intentions to shop using internet catalogues: exploring the effects of product types, shopping orientations, and attitudes towards computers. Electronic Markets, 10(1), 29-38. http://dx.doi.org/10.1080/10196780050033953 
Wang, M. S., Chen, C. C., Chang, S. C., \& Yang, H. Y. (2007). Effects of Online Shopping Attitudes, Subjective Norms and Control Beliefs on Online Shopping Intentions: A Test of the Theory of Planned Behavior. International Journal of Management, 24(2), 296-302.

Weiss, M. J. (2001). Online America. American Demographics, 23(3), 53-56.

Xiao, B., \& Benbasat, I. (2007). E-commerce product recommendation agent: Use, characteristics, and impact. MIS Quarterly, 31(1), 137-209.

Yang, B., Lester, D., \& James, S. (2007). Attitudes toward buying online as predictors of shopping online for British and American respondents. Cyber Psychology and Behavior, 10(2), 198-203. http://dx.doi.org/10.1089/cpb.2006.9968

Ying, Y. (2006). Essay on modeling consumer behavior in online shopping environments. Doctoral dissertation, University of Michigan, USA.

Yu, T., \& Wu, G. (2007). Determinants of Internet Shopping Behavior: An Application of Reasoned Behavior Theory. International Journal of Management, 24(4), 744-762.

Zhou, L., Dai, L., \& Zhang, D. (2007). Online shopping acceptance model - A critical survey of consumer factors in online shopping. Journal of Electronic Commerce Research, 8(1), 41-62.

\section{Appendix A}

\section{QUESTIONNAIRE}

Section-1: In this section you will be asked about attributes of online shopping. Please indicate the number that best indicates the degree to which you agree or disagree with each of the following statements. 1 means Strongly Disagree" and 7 being "Strongly Agree".

1. I shop online as I can shop in privacy of home

$$
1234567
$$

2. I shop online as I do not have to leave home for shopping

1234567

3. I shop online as I can shop whenever I want

$$
1234567
$$

4. I shop online as I can then save myself from chaos of traffic

$$
1234567
$$

5. I shop online as I can save myself from market crowd

$$
1234567
$$

6. I shop online as I can get detailed product information online

$$
1234567
$$

7. I shop online as I get broader selection of products online

$$
1234567
$$

8. Online shopping gives facility of easy price comparison (Hence, price advantage)

$$
1234567
$$

9. I shop online as I get user/expert reviews on the product

1234567

10. I shop online as there is no embarrassment if I do not buy

1234567

11. I shop online as I can take as much time as I want to decide 1234567 
12. I use online shopping for buying products which are otherwise not easily available in the nearby market or are unique (new)

$$
1234567
$$

13. Online shopping makes my shopping easy

$$
1234567
$$

14. Online shopping gives me better control on my expenses

$$
1234567
$$

15. I find online shopping compatible with my life-style

$$
1234567
$$

16. Using Internet for shopping requires a lot of mental effort

$$
1234567
$$

17. Online shopping procedure is cumbersome and frustrating

$$
1234567
$$

Section-2: In this section you will be asked about perceived risks, shopping habits and shipping of online shopping. Please indicate the number best indicates the degree to which you agree or disagree with each of the following statements. 1 means "Strongly Disagree" and 7 being "Strongly Agree".

\section{Perceived Risks:}

1. I feel that my credit-card details may be compromised and misused if I shop online

$$
1234567
$$

2. I might get overcharged if I shop online as the retailer has my credit-card info

$$
1234567
$$

3. I feel that my personal information given for transaction to the retailer may be compromised to 3rd party

$$
1234567
$$

\section{Product Risk:}

4. I might not get what I ordered through online shopping

$$
1234567
$$

5. I might receive malfunctioning merchandise

$$
1234567
$$

6 . It is hard to judge the quality of merchandise over Internet

$$
1234567
$$

Convenience Risk:

7. Finding right product online is difficult

$$
1234567
$$

8. If I shop online I cannot wait till the product arrives

$$
1234567
$$

9. I cannot get to examine the product when I shop online

$$
1234567
$$

10. I feel that it will be difficult settling disputes when I shop online

1234567

11. It is not easy to cancel orders when shop online 
12. I will have problem in returning product bought online (Will have to send the product back through some shipper and wait to see if the retailer accepts it without any hassle)

1234567

Non-delivery Risk:

13. I might not receive the product ordered online

1234567

14. I do not shop online because of non-availability of reliable \& well-equipped shipper

1234567

\section{Return Policy:}

1. I do not purchase online if there is no free return shipment service available

1234567

2. I purchase online only when I can return the product without any frills or strings attached

1234567

3. I do not purchase online if there is no money back guarantee

1234567

\section{Cyber laws:}

4. I would shop online without any fear if there are strict cyber-laws in place to nab and punish frauds and hackers

$$
1234567
$$

\section{Shipping charge:}

5. I do not like being charged for shipping when I shop online

1234567

\section{After Sales Service:}

6. Getting good after sales service is time taking and difficult for online purchases

1234567

Section-3: The following questions try to assess some factors that are likely to influence your online shopping intention. Please indicate the number best indicates the degree to which you agree or disagree with each of the following statements. 1 means "Strongly Disagree" and 7 being "Strongly Agree".

1. Using Internet for online shopping is easy

1234567

2. Shopping online is fun and I enjoy it

1234567

3. I like to shop with my family members or friends

$$
1234567
$$

4. When I make a purchase my friend's opinion is important to me

$$
1234567
$$

5. I will have no problem in shopping online if I get to know that my friends and relatives are doing it without any problems

$$
1234567
$$

6. Sharing my experience through online product reviews will make me noticeable 
7. I do not shop online because Internet speed (Web page download time) is very slow

1234567

8. I do not shop online as I do not have a computer at home

1234567

9. I do not shop online as I do not have a computer with Internet connection

1234567

10. I do not shop online as I do not have a credit-card

1234567

11. I am confident of shopping online even if no one is there to show me how to do it

$$
1234567
$$

12. I feel confident of using Internet for shopping after seeing someone else using it

$$
1234567
$$

13. I am usually the first in my group to try out new technologies

$$
123456
$$

14. My friends approach me for consultation if they have to try something new

1234567

\section{Section-4:}

Part-1: The following section will just ask you about your online behavior. Please mark one of the 14 below options in terms of times spent or frequency of use. (Example: If you spend maximum out of total time spent on Internet in information search then mark it).

1. I use the Internet mostly for:

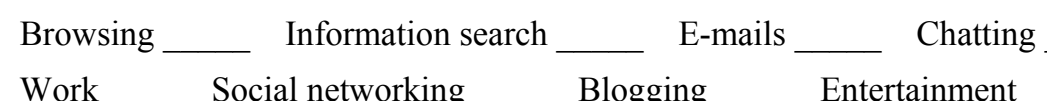

Buying ___ Banking ___ Product Search ___ Do not use
Others (Pls. specify)

Part-2: The following section will just ask you about some more questions on your online behavior. (Please select the one you find most appropriate in your case).

2. I use Internet mostly at:

Home - Work/School - Internet Café - Do not use

Others (Pls. specify)

3. For how long you have been actively using the Internet:

Less than 3 Months - 3-6 Months - 6-12 Months - $1-2$ Years - 2-3 Years - $3-5$ Years - More than 5 Years - Do not use at all

4. If you have been, then for how long you have been using Internet for shopping:

Less than 3 Months - 3-6 Months - 6-12 Months - 1-2 Years - 2-3 Years - 3-5 Years

- More than 5 Years - Do not use at all

5. If you have, then how many times have you bought things on Internet (during the past six months)?

Never - 1-2 times - 3-5 times - 6-10 times - 11-20 times - 21 times or more - Not sure

6. What do you prefer buying from Internet?

Apparels - Electronic goods - Books Cinema Tickets / Online Movies /Shows - Financial Services or Banking - Stuff available only online - Anything - Do not buy online - Unique daily use items (e.g.: Torch with blinker light, car seat belt cutter and hammer (all in one) or an artifact)

7. In the past 6 months what would be your estimate of online expenditure (in IRR)? 
$\begin{array}{lllllll}0 & 1-10000 \quad 100001-50000 & 50001-150000 & 150001-300000 & 300001-500000 & 500001+\end{array}$

9. Do you currently own your own computer? Yes No

10. Do you have an Internet connection at home? Yes No

11. What kind of Internet connection do you have? Dial-up - DSL - Through some cable network - Do not have

12. Do you have a credit-card? Yes No

13. How do you pay for online shopping?

Credit Card - Debit Card - Cash Card - Cheques - Cash on delivery - Wiretransfer - Never bought online Others (Pls. Specify

14. I will grade my Internet using skills as:

Skilled - Knowledgeable - Less Knowledgeable - Want to learn Internet search and browsing techniques.

\section{Section-5:}

Please tick the option that you find most suitable:

1. What is your age?

Under $21-21-29-30-39-40-49-50(+)$

2. What is your gender? Male Female

3. Number of people living in your household (including yourself):

4. In what industry do you work (e.g. medicine, academia, student, etc.)?

5. Marital Status:

Single or Never Married - Married - Widowed - Divorced/Separated 